\title{
Energy performance and cost analysis for the nZEB retrofit of a typical UK hotel.
}

Radwa Salem ${ }^{1}$, Ali Bahadori-Jahromi ${ }^{1 *}$, Anastasia Mylona ${ }^{2}$, Paulina Godfrey ${ }^{3}$, and Darren Cook ${ }^{4}$

${ }^{1}$ Department of Civil Engineering and Built Environment, School of Computing and Engineering, University of West London, London W5 5RF, UK

${ }^{2}$ Technical Department, The Chartered Institution of Building Services Engineers (CIBSE), London SW12 9BS, UK

${ }^{3}$ Energy and Environment, Engineering Operations EMEA, Hilton, Maple Court, Reeds Crescent, Watford WD24 4QQ, UK

${ }^{4}$ Engineering Operations EMEA, Hilton, Maple Court, Reeds Crescent, Watford WD24 4QQ, UK

Corresponding author: Ali.Bahadori-Jahromi@uwl.ac.uk

Conflict of interest: the authors declare that they have no conflict of interest

Abstract:

It is commonly known that commercial buildings contribute to a large proportion of energy consumption nationally and across Europe. The introduction of 'nearly zero energy buildings' (nZEBs) by the Energy Performance Building Directive [Recast] in 2010 has meant that a variety of active measures must be undertaken by the construction industry to define, shape, and meet the standard for both residential and commercial buildings. Hotels are typically ranked amongst the top five energy consumers in the tertiary sector. However, energy saving potential within the hotel industry is also significant. The aim of this study is to present an energy performance analysis and identify the primary energy consumption (PEC) level, post-retrofit, which could represent the cost-optimal level for a UK nZEB-hotel. Thermal Analysis Simulation software (Tas) is used to validate and assess the energy performance of the building pre- and post-retrofit. TasGenOpt is used to select individual EEMs that meet the nZEB targets and create the retrofit scenarios. Finally, building life cycle cost (BLCC) software is used to carry out the global cost calculations. It is found that whilst the nZEB target is technically feasible there is a 30 percent gap between the nZEB solution and the cost-optimal one. This is significant as it means that the current nZEB standard is not comparable to the best financial solution. The identified cost-optimal PEC level and recommendations provided may be used in the appraisal of other purposebuilt UK nZEB hotel retrofits.

Keywords: nearly-zero energy buildings, dynamic energy simulation, life cycle costs, hotel, cost-optimal

\begin{tabular}{|c|c|c|c|}
\hline \multicolumn{4}{|c|}{ List of Notations/Abbreviations } \\
\hline ASHP & Air source heat pump & nZEB & Nearly zero energy building \\
\hline BLCC & Building life cycle cost & neZEH & Nearly zero energy hotel \\
\hline $\mathrm{CO}_{\mathrm{a}}$ & Annual costs & PEC & Primary energy consumption \\
\hline $\mathrm{C}_{\mathrm{G}}$ & Global costs & PV & Photovoltaic panels \\
\hline $\mathrm{CO}_{\text {INIT }}$ & Investment costs & PUR & Rigid polyurethane foam \\
\hline COP & Coefficient of Performance & PIR & Polyisocyanurate \\
\hline $\mathrm{CO}_{2}$ & Carbon Dioxide & NOx & Nitrogen oxide \\
\hline CFL & Compact fluorescent light & PM & Particle pollution \\
\hline DHW & Domestic hot water & PAHs & Polycyclic Aromatic Hydrocarbons \\
\hline EEMs & Energy efficient measures & Rd & Discount factor \\
\hline EPBD & Energy performance building directive & SWH & Solar water heating \\
\hline GSHP & Ground source heat pump & $\tau_{0}$ & Starting year \\
\hline HVAC & Heating, ventilation and air conditioning & $T C$ & Calculation period \\
\hline$i$ & Year & Tas & Thermal analysis simulation \\
\hline$j$ & Component & U & Thermal transmittance $(\mathrm{W} / \mathrm{m} 2 \mathrm{k})$ \\
\hline LCCA & Life cycle cost analysis & VRF & Variable refrigerant flow \\
\hline LED & Light emitting diode & $V A L_{\text {fin }}$ & Residual value \\
\hline
\end{tabular}




\subsection{Introduction}

The commercial sector accounted for the largest proportion of final energy consumption (total energy consumed by end users) within the UK between 2017-2018 [1]. Across Europe they contributed to $40 \%$ of total energy consumption [2].

The introduction of nearly zero energy buildings (nZEBs) by the European energy performance building directive (EPBD) [recast] in 2010, reflects the high potential energy savings associated with designing and retrofitting energy efficient buildings. The design, retrofit, and cost analysis of residential nZEBs has been explored over the past few years across several literature studies [3-6]. However, fewer studies have focussed on the nZEB retrofit of commercial buildings and the life cycle costs (LCCS) associated with such retrofits. The hotel sector represents a bigger challenge in terms of retrofitting to the nZEB standard and this is largely due to the hosting elements of the business which means customer comfort, care, and services are a top priority. Therefore, any retrofit solution should ideally allow implementation whilst the hotel is operating and with minimal disruptions to occupants.

The EPBD [recast] defines nZEBs as buildings that have a "very high energy performance... and the nearly zero energy should be covered to a very significant extent by energy from renewable sources" $[7,8]$. The EPBD's ambiguous definition means member states are required to develop clear and specific definitions that are in consonance with their national level of ambition, climatic conditions, and level of technology. Whilst some countries have begun establishing definitions, the UK has yet to release an official definition for commercial nZEBs. Furthermore, the EPBD states that, in cases where a cost-benefit analysis of the economic lifecycle of a building is conducted and proven to be negative rather than positive, then the nZEB standard does not need to be applied [8,9]. Meaning that increased efforts are necessary to ensure and prove that commercial buildings are reaching the nZEB standard with economic benefits.

Energy consuming activities within a hotel can be split into two main categories one of which would be any activities that involves the guests and their comfort. For example, guests' rooms, reception, bar and restaurant. Meanwhile other activities that do not directly involve the guests include kitchen, laundry etc. It has been reported that activities that do not directly involve guests are typically the largest contributors to the total energy consumption of the hotel [4-6]. This suggests that a focus on reducing the energy demand of such activities through the incorporation of relevant energy efficient measure (EEMs) would lower the overall energy demand and increase the energy efficiency of the hotel building.

There is evidence that commercial nZEB retrofit projects make up a smaller percentage of overall nZEB retrofits. One paper identified four main reasons why retrofits may not be taken up as much for commercial buildings. Three of the reasons are due to financial aspects of the retrofit, namely, stakeholders may only look at short-term profitability, there is inconsistent data about profitability and budgetary constraints [10]. This highlights the importance of selecting retrofit solutions that are economically viable. Most importantly, that this can also be demonstrated to stakeholders. Currently within the UK there have been no investigations into the retrofitting of hotel buildings to the nZEB standard and analysing their life cycle costs (LCCS). Within this context, this paper aims to present an nZEB energy retrofit of a UK hotel whereby the life cycle costs of the retrofit packages are explored, and a cost-optimal benchmark is identified. The methodology utilised in this paper is one of few that validate the simulation modelling results by comparing the model's energy consumption with the real energy consumption. It has been noted throughout the literature that the performance gap of such models is typically $30 \%+[11-13]$. Because this paper aims to provide tangible recommendations on how to achieve the nZEB standard with economic benefits, having an accurate model is vital. 
The methodology is comprised of several steps. Firstly, Thermal Analysis Software (Tas) is utilised to provide an accurate prediction of the energy consumption, primary energy consumption (PEC), $\mathrm{CO}_{2}$ emissions, building fabric and thermal performance of the building [14]. To ensure validity of the baseline model, the actual building energy consumption is compared to the baseline model's energy consumption. The actual data was collected during the site survey stage of this investigation. Although this approach is time consuming, it ensures that the study's outcomes are valid and applicable to other buildings of the same stock. Once the baseline model has been simulated and validated, the EEMs are individually simulated. Subsequently, the EEMs are combined to form sets of retrofit scenarios. Finally, a LCCA is carried out using building life cycle cost software (BLCC) and a cost optimal solution is selected using the EPBD's cost-optimal curve calculation methodology. The methodology utilised can be replicated by any researcher or designer wishing to find a cost-optimal solution for a building retrofit where a valid and representative model is important.

\subsection{Literature review}

Many studies have assessed the energy consumption of the hotel industry and have often concluded that hotels are typically energy intensive buildings $[15,16]$. Lowering the energy consumption in hotels through the implementation of individual EEMs or a whole building retrofit can offer not only environmental benefits but also financial ones. This is corroborated in the findings of the 'nearly zero energy hotel' (neZEH) project which highlighted that the hotel industry in general acknowledged the financial benefits of retrofitting not only as a result of reduced operational and maintenance costs but also due to increased competitiveness as a result of improved image [16]. This is in consonance with many other studies [17-21].

The above demonstrates that a lot of research effort has been undertaken to investigate the importance of improving the energy performance of hotels. Table 1 is included to offer a brief overview of hotel retrofits in general and the factors that encourage/discourage hoteliers' and guests decision when it comes to retrofitting and staying in a 'green hotel,' respectively. From table 1, it is learnt that both guests and hoteliers appreciate the importance of an environmentally friendly hotel. However, further encouragement is required to ensure that hoteliers are fully aware of the financial benefits of improving the energy efficiency of their building. In addition, official incentive schemes should be introduced to also encourage and assist hoteliers in making the transition towards an energy efficient hotel.

A paper which aimed to assess how realistic the nZEB standard within the hotel sector in Southern Europe concluded that whilst the nZEB vision "in hotels is close to reality" and can be economically attractive it remains challenging due to hotel buildings' individualities and therefore complexities [22]. Most non-residential buildings typically have fixed operating hours whereas hotels can operate around the clock. This adds to the complexity of identifying energy use patterns.

A 2017 study analysed 411 nZEBs across 17 EU countries (using the zebra2020 data tool) and found that that renovated buildings made up just $19 \%$ of the sample and commercial buildings represented $36 \%$ of this [23]. Those percentages further reflect the slow progress that is being made towards reaching the nZEB standard for commercial buildings. This is also reflected in the literature, whereby majority of studies focus on investigating the nZEB standard for residential buildings. When considering commercial building retrofit several issues arise such as the limited number and type of 
energy efficient measures (EEMs) that can be incorporated due to several reasons such as the continuous occupancy and usage, irregular frame types and existing materials, and the need to uphold certain aesthetics. Moreover, on average a residential building's energy needs can be met with just renewable systems. On the other hand, commercial buildings can have up to five times the energy demand of a residential building. This combined with the constraints above means it can be more challenging to achieve the nZEB standard with cost benefits for commercial buildings.

Using an Italian reference hotel one paper investigated whether there is a match between the costoptimal solution and the nZEB solution [24]. It was found that the financial analysis presented a 'worrying gap' between financially optimal solutions and the nZEB ones. This is unsurprising as various studies investigating the currently available nZEB definitions concluded that many of the national plans being released and implemented have "missing or vague information" $[25,26]$. In general, the energy consumption between hotels varies depending on the size, quality and type of service, and occupancy rates. Tournaki et al. [27] suggested some reference levels for nZEB hotels: 77-134 $\mathrm{kWh} / \mathrm{m}^{2} / \mathrm{yr}$ for new builds and $93-175 \mathrm{kWh} / \mathrm{m}^{2} / \mathrm{yr}$ for existing builds (depending on the climatic zones).

In terms of technical feasibility, a paper presented the actual primary energy consumption decrease of six southern and one northern European hotel that were part of the neZEH project [23]. The results proved that a 'dramatic' decrease in the primary energy consumption (PEC) was achievable with an average reduction of $63 \%$ amongst the examined hotels. It was noted that activities that do not directly involve guests were more critical in terms of reducing the PEC. Several studies $[3,17,23,28]$ highlighted that with hotel nZEB retrofit it is essential that the energy demand of the building is initially lowered by improving the building fabric and envelope elements prior to incorporating a renewable/microgeneration system.

Another study examined the technical and economic aspects of various retrofit measures on a typical 4-star hotel located in the South of Portugal (Faro). They concluded that the cost-optimal solutions include control of equipment, systems, improving water use efficiency, efficient lighting, and total redesign of the ventilation system [29]. Using two Italian reference buildings it was [30] found that a heat pump combined with a PV system seemed to be the most cost-effective solution to meeting the nZEB Italian standard requirements. Several studies found that installing renewable energy systems to substitute traditional fossil fuels had competitive economic payback periods [6,31,32]. A similar study looked at investigating the performance gap between cost-optimal and nZEB retrofit options for an Italian reference hotel and concluded that any solution that me the nZEB standard had a global cost at least $50 \%$ higher than the cost-optimal solution. It was also noted that retrofit packages with better economic performances exhibited poorer comfort levels [24].

One paper investigated reaching the nZEB standard on several reference buildings from various countries [33]. It was found that there appears to be a pattern between the nZEB building regardless of location. For example, the nZEB building typically has high levels of insulation, double or triple glazing (depending on local climate), an efficient boiler or ground source heat pump (GSHP) and a renewable solar system. However, whilst it was noted that the nZEB retrofit did not vary significantly, the same could not be said for the cost-optimal benchmark. Furthermore, it was difficult to reduce global costs (energy, investment, replacement and maintenance costs) whilst ensuring the standard is fully met. Furthermore, it was highlighted that one of the most significant barriers to obtain a valid and reliable cost analysis is the collection of reliable data for the renovation costs 
Given the current absence of the UK's national nZEB definition it is necessary to utilise a different approach to setting the standard. Following on from previous work, this paper utilises the EU zebra2020 project to come up with a definition that is both numerical and specific to UK nonresidential nZEBs. The EU zebra2020 project was launched in 2014 with the purpose of presenting nZEB building indicators and establishing strategies to resolve barriers to reaching the nZEB standard across Europe [34]. The project synthesised data from numerous nZEB case studies which allowed a quantitative and qualitative analysis on the performance and key characteristics of successful nZEBs across Europe to be carried out.

The tool is one of the few databases that cover $90 \%$ of the existing nZE building stock. the tool is the 'nZEB Tracker' which offers building information for existing successful nZEB case studies and their relevant indicators such as the primary energy performance, passive and active energy efficient solutions and types of renewables utilised. The tool separates those indicators for residential and nonresidential buildings and the information is presented by country, therefore, the tool is used to aggregate a definition with numerical targets specific to UK hotel nZEBs. Refer to Salem et al. 2019b for more information on the selected nZEB definition. Table 2 is showing the nZEB target for this case study.

Table 1: Literature review summary

Journal Author(s)

1) Energy Conversion and Management

2) Entropy

Cornell Hospitality

Quarterly

1) Nocera et al. 2019 [36]

1) Butler 2008 [37]

2) Dolnicar, Crouch, and Long 2008 [38]

1) Renewable Energy

2) International Journal of Hospitality Management

International conference GREDIT

Cingoski and Petrevska 2018 [41]

1) Kostakis and Sardianou 2012 [39]

2) Chen and Tung 2014 [40]
Findings

* One-star hotel managers/owners are less likely to be willing to invest in renewable energy and energy efficient retrofit of their buildings in comparison to 2-5-star hotels

* Green hotels have better performance in terms of thermal comfort, acoustics, lighting, and indoor air quality [1]

* Although financial benefits can be gained from the overall reduction in energy consumption associated with green hotels, hoteliers are reluctant to implement measures that may lead to the discomfort of guests [2]

* Guests are willing to pay more for environmentally friendly hotels [1,2]

* Guests do not mind minor discomfort (e.g. reusing towels, using recycled products) if it means helping the hotel remain green and helping the environment [2]

* Factors that affect whether guests are more willing to pay for a green hotel are gender, age, and level of environment consciousness and awareness [1, 2]

* Contemporary guests "expect" hotels to be environmentally responsible

* The case-study (a 5-star) hotel was willing to become an ecohotel due to the perceived benefits of lowering operational costs and energy consumption

* It was recommended that the introduction of subsidies will encourage more hoteliers to run a high energy efficient hotel

* Social/government pressure to retrofit has a weak influence on hoteliers' decision to retrofit, unlike perceived competition and customer demand.

* Building characteristics such as the size and location of the building had a weak influence on decision to retrofit. 
Table 2: Building fabric, energy consumption, primary energy consumption and carbon emissions of the nZEB target as aggregated from Zebra2020 tool

\begin{tabular}{|c|c|}
\hline & nZEB Target \\
\hline Wall $\left(\mathrm{W} / \mathrm{m}^{2} \mathrm{~K}\right)$ & 0.11 \\
\hline Floor $\left(\mathrm{W} / \mathrm{m}^{2} \mathrm{~K}\right)$ & 0.10 \\
\hline Roof $\left(W / m^{2} K\right)$ & 0.15 \\
\hline Windows (W/m²K) & 0.92 \\
\hline Air permeability rate $\left(\mathrm{m}^{3} / \mathrm{h} / \mathrm{m}^{2} @ 50 \mathrm{~Pa}\right)$ & 2.00 \\
\hline Primary Energy Consumption (kWh/m²) & 150 \\
\hline Carbon Emissions $\left(\mathrm{Kg} / \mathrm{CO}_{2} / \mathrm{m}^{2}\right)$ & At least $50 \%$ reduction in annual Carbon Emissions \\
\hline
\end{tabular}

\subsection{Methodology}

\subsection{Case study and modelling details}

The selected case study is Hilton Watford hotel located in Elton Way, Watford. It is a purpose-built hotel constructed in the early 1990s. The hotel building is spread mainly over two floors. It is constructed of traditional bricks, a flat roof, and double-glazed windows [see table 3 for further detail]. The building core occupancy hours are 24 hours, 7 days a week due to the nature of the business. The total building floor area is $10,695 \mathrm{~m}^{2}$ and $2,825 \mathrm{~m}^{2}$ of conditioned floor space.
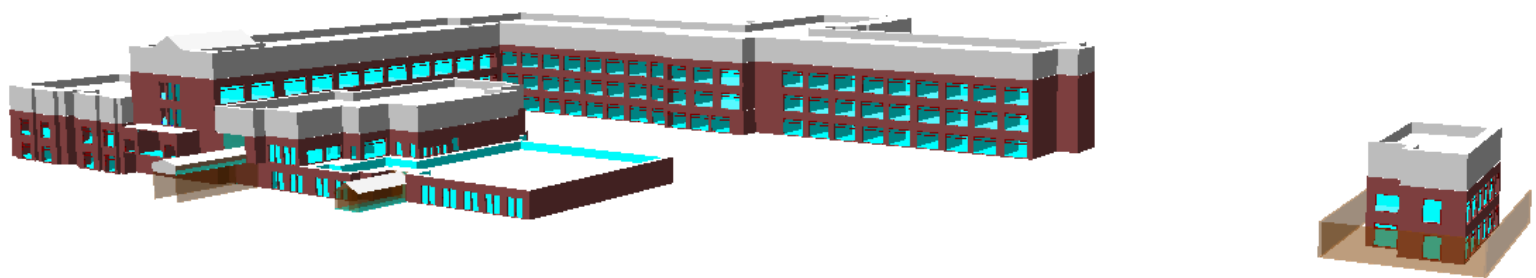

Figure 1: 3D model of the case study building

The building is cooled by one main chiller, direct expansion (DX) air conditioning units, variable refrigerant flow (VRF) systems, and multi single/ multi split systems. The systems provide cooling to restaurant/bar, conference suites, TV Comms room, lift motor room, meeting rooms, gym, leisure clubs, and back of office areas, along with three air handling units supplying and extracting fresh air across various areas. The terminal units used within site are linear supply air diffusers, fan coil units, ducted units, ceiling cassettes, and wall mounted units. The systems are controlled via one main building management system, hard wired controllers, and individual remote controllers. The total installed cooling capacity is $490 \mathrm{~kW}$.

\begin{tabular}{|c|c|c|}
\hline \multicolumn{3}{|l|}{ Use } \\
\hline Building fabric & Type & $\begin{array}{l}\text { Traditional build }{ }^{1} \text { including block, bricks, and precast units } \\
\text { (stair-case and slabs) }\end{array}$ \\
\hline Occupancy rate & & $24 / 7$ \\
\hline $\begin{array}{l}\text { Wall (calculated area } \\
\text { weighted average u-values) }\end{array}$ & $U$-value $\left(\mathrm{W} / \mathrm{m}^{2} \mathrm{~K}\right)$ & 0.45 \\
\hline \multirow{2}{*}{$\begin{array}{l}\text { Roof (calculated area } \\
\text { weighted average u-values) }\end{array}$} & Type & Flat - Single-Ply Membrane \\
\hline & $U$-value $\left(\mathrm{W} / \mathrm{m}^{2} \mathrm{~K}\right)$ & 0.35 \\
\hline \multirow[t]{2}{*}{$\begin{array}{l}\text { Floor (calculated area } \\
\text { weighted average u-values) }\end{array}$} & Type & $\begin{array}{c}\text { Ground \& first floor: cast concrete slab } \\
\text { Other floors: precast slab }\end{array}$ \\
\hline & $U$-value $\left(\mathrm{W} / \mathrm{m}^{2} \mathrm{~K}\right)$ & 0.35 \\
\hline \multirow{2}{*}{$\begin{array}{l}\text { Windows (calculated area } \\
\text { weighted average u-values) }\end{array}$} & Type & Double glazing (air-filled) \\
\hline & $U$-value $\left(\mathrm{W} / \mathrm{m}^{2} \mathrm{~K}\right)$ & 2.0 \\
\hline $\begin{array}{l}\text { Zone - occupancy levels, } \\
\text { people density, lux level }\end{array}$ & NCM constructions database -v5.2.tcd & $\begin{array}{l}\text { Car Park }-0.0059 \text { person } / \mathrm{m}^{2}, 100 \text { lux } \\
\text { Bedroom }-0.094 \text { person } / \mathrm{m}^{2}, 100 \text { lux }\end{array}$ \\
\hline
\end{tabular}




\begin{tabular}{|c|c|}
\hline & $\begin{array}{c}\text { Toilet - } 0.1188 \text { person } / \mathrm{m}^{2}, 200 \text { lux } \\
\text { Reception }-0.105 \text { person } / \mathrm{m}^{2}, 200 \mathrm{lux} \\
\text { Hall }-0.183 \text { person } / \mathrm{m}^{2}, 300 \mathrm{lux} \\
\text { Food prep/ kitchen- } 0.108 \text { person } / \mathrm{m}^{2}, 500 \mathrm{lux} \\
\text { Eat/Drink area }-0.2 \text { person } / \mathrm{m}^{2}, 150 \mathrm{lux} \\
\text { Circulation }-0.115 \text { person } / \mathrm{m}^{2}, 100 \mathrm{lux} \\
\text { Store- } 0.11 \text { person } / \mathrm{m}^{2}, 50 \mathrm{lux} \\
\text { Laundry }-0.12 \text { person } / \mathrm{m}^{2}, 300 \text { lux } \\
\text { Changing room }-0.112 \text { person } / \mathrm{m}^{2}, 100 \mathrm{lux} \\
\text { Plant room } 0.11 \text { person } / \mathrm{m}^{2}, 50 \text { lux } \\
\text { Office }-0.106 \text { person } / \mathrm{m}^{2}, 400 \text { lux } \\
\text { Meeting room }-0.094 \text { person } / \mathrm{m}^{2}, 100 \text { lux }\end{array}$ \\
\hline Air permeability & $7 \mathrm{~m}^{3} / \mathrm{h} / \mathrm{m}^{2} @ 50 \mathrm{~Pa}$ \\
\hline Infiltration & $0.500 \mathrm{ACH}$ \\
\hline Lighting Efficiency & $5.2 \mathrm{~W} / \mathrm{m}^{2}$ per 100 lux \\
\hline \multirow[t]{2}{*}{ Fuel Source } & Natural Gas $-\mathrm{CO}_{2}$ Factor $-0.198 \mathrm{Kg} / \mathrm{kWh}$ \\
\hline & Grid Electricity $-\mathrm{CO}_{2}$ Factor $-0.4121 \mathrm{Kg} / \mathrm{kWh}$ \\
\hline Orientation & Latitude: 51.6653 ; Longitude $-0.3609^{\circ} \mathrm{W} ;+0.0$ UTC \\
\hline Weather data & $\begin{array}{l}\text { TRY (Cibse) for London. Includes: dry bulb temperature }\left({ }^{\circ} \mathrm{C}\right) \text {; } \\
\text { wet bulb temperature }\left({ }^{\circ} \mathrm{C}\right) \text {; atmospheric pressure }(\mathrm{hPa}) ; \text { global } \\
\text { solar irradiation }\left(\mathrm{W} \cdot \mathrm{h} / \mathrm{m}^{2}\right) \text {; diffuse solar irradiation }\left(\mathrm{W} \cdot \mathrm{h} / \mathrm{m}^{2}\right) ; \\
\text { cloud cover (oktas); wind speed (knots); wind direction } \\
\text { (degrees clockwise from North); and Present Weather Code. }\end{array}$ \\
\hline
\end{tabular}

According to the EPBD [244/2012] in order to carry out a life cycle cost analysis (LCCA) for a nZEB retrofit, EEMs should be individually selected and grouped into retrofit packages. The baseline model/building forms one of those packages and is used as a comparison point for improvements on energy and costs for each of the retrofit packages. To select a cost-optimal solution the EPBD has suggested a cost-optimal range methodology. The cost-optimal solution is identified as the lowest point along the range of the different solutions, as demonstrated in figure 2 . According to annex I of the EPBD "the energy performance of a (nZEB) building shall be expressed in a transparent manner and shall include an energy performance indicator and a numeric indicator of primary energy use, ..." $[7,8]$. Consequently, the energy performance indicator for this study is the PEC and this is be considered on an annual basis.

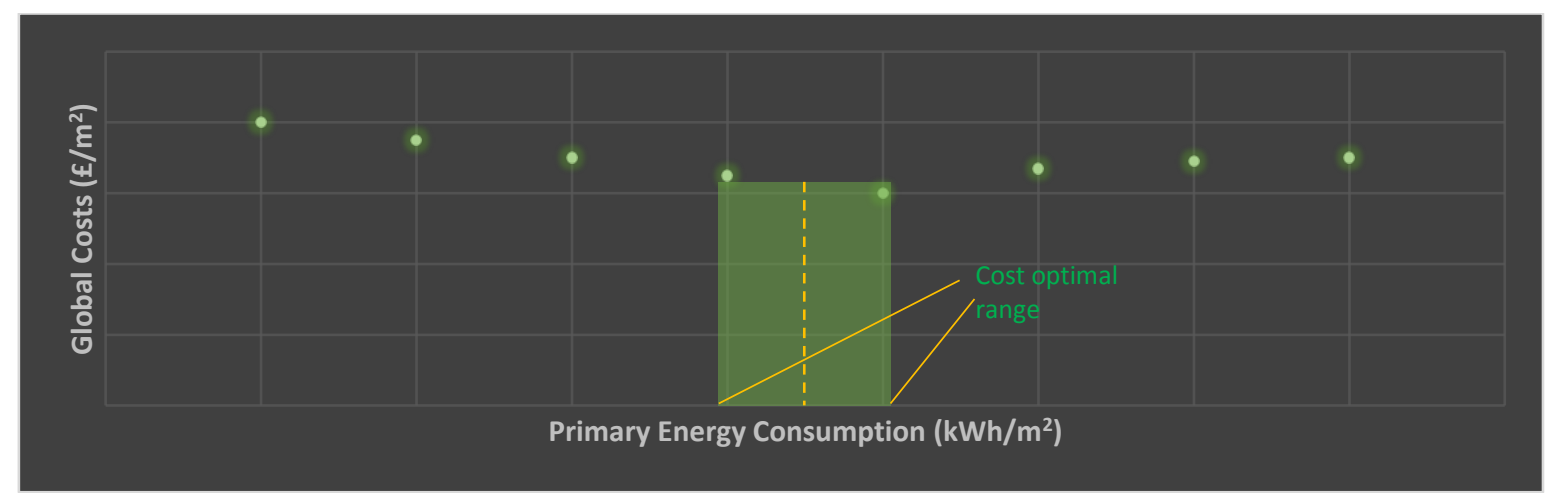

Figure 2: Reproduced example of a cost-optimal graph

The methodology applied in this paper is split into four main phases:

Actual site data: this phase involves conducting a site visit to collect AutoCAD plans, information regarding the actual building construction, systems, and plant details, as described above. This allows the creation of a model that is a replica of the current state of the building. In addition, the actual monthly and annual energy consumption is collected for the latest year and the previous two years for comparison and validation. 
Tas software: the site data that is collected from the first phase is used to build a holistic baseline model on Tas. The EPBD [recast] suggests that the typical energy use in a building (heating, cooling, ventilation, lighting, and DHW) needs to refer the indoor environmental parameters. For UK hotels this refers to BS EN 16798-1:2019 [42]. Consequently, the standard zones that are applied within the model are guests' rooms, receptions hall, offices, meeting rooms, bar, and restaurant.

When populating the TBD file, such as filling out typical constructions of the building envelope, it is ensured that they represent the building's constructions, building fabric, glazing and year of construction. Once this is done the building's systems are specifically and individually designed within Tas systems utility to replicate the current HVAC systems/plants. Refer to [43] for full details on the simulation process.

The retrofit phase of the methodology begins by utilising TasGenOpt v3.1.1 to select individual EEMs that are applicable to the case study and create the retrofit scenarios that meet the nZEB target. TasGenOpt is a utility within Tas software that performs parametric simulations. It minimises the number of simulations and time needed to achieve desirable design options (in this case the nZEB target values). GenOpt has been used in numerous studies across the literature [44-47] and has proven to deliver required results. Refer to Salem et al. 2019a for further detail of TasGenOpt.

CIBSE weather data: The Cibse weather datasets are based on a 30-year timeline and it is generally recommended that where possible the weather file selected should be in close proximity to the location of the case study being examined [48]. Tas, and other simulation software recommend that the existing pre-selected 'typical years' weather files that are within 20-30miles (30-50km) of the case study will most closely match the long-term climatic temperature, solar radiation, and other relevant variables. The relevant weather file selected for carrying out the analysis is the Test Reference Year (TRY). This is selected because the Design Summer Year (DSY) weather file is suitable for overheating analysis, meanwhile the Test Reference Year (TRY) is suitable for "energy analysis and for compliance with the UK Building Regulations (Part L)" (48-50).

Finally, the model is simulated after all the details has been inputted and the U-values, energy consumption, carbon emissions etc. are all calculated and generated by Tas. To ensure the results are valid and represent the actual building the second part of the actual site data is then compared and the percentage error/difference is calculated to validate the model.

BLCC software: Building life cycle cost (BLCC) software is used to carry out the global cost calculations. For each retrofit package the global costs are calculated, and the data gathered is used to generate the cost-optimal graph. Based on this the global costs for the cost-optimal solution/range can be compared with the baseline model's PEC and global costs and the nZEB target. Therefore, the energy and cost benefits of the retrofit process can be analysed and evaluated.

The retrofit packages are split into four categories, as shown in table 4. Table 5 is showing the list of individual EEMs that have been selected to aggregate the retrofit packages for this hotel. Overall, the individually considered measures formed $<190$ nZEB retrofit packages. In total there are 46 nZEB retrofit packages for each set and they have been labelled as EP1.1-EP1.46 [see figure 3]. Each EEM has been defined by its own individual code such as "ig 1.0". Selecting which EEM to consider is a critical step of the retrofit process as the selection of unsuitable measures that are incompatible with the energy needs of the building can lead to the aggregation of unsuitably large and expensive packages.

The investment costs are obtained from various UK databases that provide figures for the retrofit of commercial buildings. The absence of an official database means it is only possible that figures are 
obtained from various databases. Studies and reports have highlighted that there needs to be "an approved products and suppliers list for commercial property retrofit" [51]

The specification of the EEMs is defined by the parameters shown in the last column. The parameters are selected so that they exceed the nZEB target by no more than $20 \%[\leq 20 \%]$. For example, where a wall U-value $\leq 0.15 \mathrm{~W} / \mathrm{m}^{2} \mathrm{~K}$ is stated, all the wall insulation EEMs will have a U-value less than or equal to $0.15 \mathrm{~W} / \mathrm{m}^{2} \mathrm{~K}$ (depending on the specific material and thickness). This variation is included so that there is also a variation in the energy performance and costs, and therefore LCCs. This in turn offers a range of different and possibly more cost-effective solutions. The relevant system efficiencies are also included in that column. The main areas of retrofit considerations are thermal insulation, glazing, lighting, heating, ventilation, cooling, DHW, and incorporating a renewable/microgeneration system.

\begin{tabular}{|c|c|c|}
\hline Set & Description & Example \\
\hline 1 & $\begin{array}{l}\text { Significant fabric and lighting improvements, assisted by little } \\
\text { improvements to HVAC and undersized renewable/ microgeneration } \\
\text { systems }\end{array}$ & $\begin{array}{l}\lg 3.5+\operatorname{ig} 6.3+\mathrm{L} 3.0+\mathrm{Hd} 4.0+ \\
\text { rm3.0 }\end{array}$ \\
\hline 2 & $\begin{array}{l}\text { Significant HVAC improvements, assisted by little fabric and lighting } \\
\text { improvements and undersized renewable/ microgeneration systems }\end{array}$ & $\begin{array}{l}\lg 1.0+\mathrm{L} 2.0+\mathrm{Hd} 3.0+\mathrm{Hd} 4.0+ \\
\mathrm{rm} 4.0\end{array}$ \\
\hline 3 & $\begin{array}{l}\text { All-round retrofit i.e. selective fabric, lighting, HVAC and renewable/ } \\
\text { microgeneration systems }\end{array}$ & $\begin{array}{l}\lg 2.4+\operatorname{ig} 6.1+\mathrm{L} 1.0+\mathrm{Hd} 2.0+\mathrm{Hd} 4.1 \\
+\mathrm{rm} 2.4\end{array}$ \\
\hline 4 & $\begin{array}{l}\text { Small fabric and lighting improvements, assisted by significant HVAC } \\
\text { improvements and renewable/ microgeneration systems }\end{array}$ & $\begin{array}{l}\lg 2.0+\mathrm{L} 1.0+\mathrm{Hd} 1.0+\mathrm{Hd} 4.0+ \\
\mathrm{rm} 5.5\end{array}$ \\
\hline
\end{tabular}

Table 5: Summary of the individual EEMs utilised

\begin{tabular}{|c|c|c|c|c|c|}
\hline \multirow[t]{2}{*}{ Areas of retrofit } & \multirow[t]{2}{*}{ Code } & \multirow[t]{2}{*}{ EEM Description } & \multicolumn{2}{|c|}{ Investment cost } & \multirow{2}{*}{$\begin{array}{c}\text { Parameter(s) \& System } \\
\text { efficiencies }\end{array}$} \\
\hline & & & Unit & Cost & \\
\hline \multirow{25}{*}{$\begin{array}{l}\text { 1. Insulation \& } \\
\text { Glazing }\end{array}$} & ig1.0 & Rigid polyurethane foam (PUR), $50 \mathrm{~mm}$, 2in & $f / m^{2}$ & 30 & \multirow{25}{*}{$\begin{array}{l}U \text {-value of wall } \leq 0.15 \mathrm{~W} / \mathrm{m}^{2} \mathrm{~K} \\
\mathrm{U} \text {-value of floor } \leq 0.15 \mathrm{~W} / \mathrm{m}^{2} \mathrm{~K} \\
\text { U-value of Roof } \leq 0.20 \mathrm{~W} / \mathrm{m}^{2} \mathrm{~K} \\
\mathrm{U} \text {-value of windows } \leq 1.20 \\
\mathrm{~W} / \mathrm{m}^{2} \mathrm{k} \\
\text { Air permeability rate } \leq 2.5 \\
\mathrm{~m} 3 / \mathrm{h} / \mathrm{m} 2 @ 50 \mathrm{~Pa}\end{array}$} \\
\hline & ig1.1 & PUR, 60mm, 2in & & 37 & \\
\hline & ig1.2 & PUR, 70mm, 2in & & 45 & \\
\hline & ig1.3 & PUR, 80mm, 4in & & 55 & \\
\hline & ig1.4 & PUR, 90mm, 4in & & 60 & \\
\hline & ig1.5 & PUR, $100 \mathrm{~mm}, 4$ in & & 72 & \\
\hline & ig2.0 & Polyisocyanurate (PIR), $50 \mathrm{~mm}$ & $f / m^{2}$ & 30 & \\
\hline & ig2.1 & $\mathrm{PIR}, 60 \mathrm{~mm}$ & & 35 & \\
\hline & ig2.2 & $\mathrm{PIR}, 70 \mathrm{~mm}$ & & 46 & \\
\hline & ig2.3 & $\mathrm{PIR}, 80 \mathrm{~mm}$ & & 58 & \\
\hline & ig2.4 & $\mathrm{PIR}, 90 \mathrm{~mm}$ & & 63 & \\
\hline & ig2.5 & $\mathrm{PIR}, 110 \mathrm{~mm}$ & & 71 & \\
\hline & $\lg 3.0$ & Rigid thermoset phenolic $25 \mathrm{~mm}$ & $f / m^{2}$ & 35 & \\
\hline & $\lg 3.1$ & Phenolic foam, $30 \mathrm{~mm}$ & & 46 & \\
\hline & $\lg 3.2$ & Phenolic foam, $35 \mathrm{~mm}$ & & 55 & \\
\hline & $\lg 3.3$ & Phenolic foam, $40 \mathrm{~mm}$ & & 67 & \\
\hline & $\lg 3.4$ & Phenolic foam, $45 \mathrm{~mm}$ & & 75 & \\
\hline & $\lg 3.5$ & Phenolic foam, $50 \mathrm{~mm}$ & & 83 & \\
\hline & $\lg 4.0$ & Glass wool, $140 \mathrm{~mm}$ & $\mathrm{f} / \mathrm{m}^{2}$ & 33 & \\
\hline & $\lg 4.1$ & Glass wool, $180 \mathrm{~mm}$ & & 46 & \\
\hline & $\lg 4.2$ & Glass wool, $200 \mathrm{~mm}$ & & 54 & \\
\hline & $\lg 4.1$ & Glass wool, $240 \mathrm{~mm}$ & & 66 & \\
\hline & $\lg 4.4$ & Glass wool, $280 \mathrm{~mm}$ & & 74 & \\
\hline & $\lg 4.5$ & Glass wool, 300mm & & 80 & \\
\hline & $\lg 5.0$ & Mineral Wool, 140mm & $\mathrm{f} / \mathrm{m}^{2}$ & 37 & \\
\hline
\end{tabular}




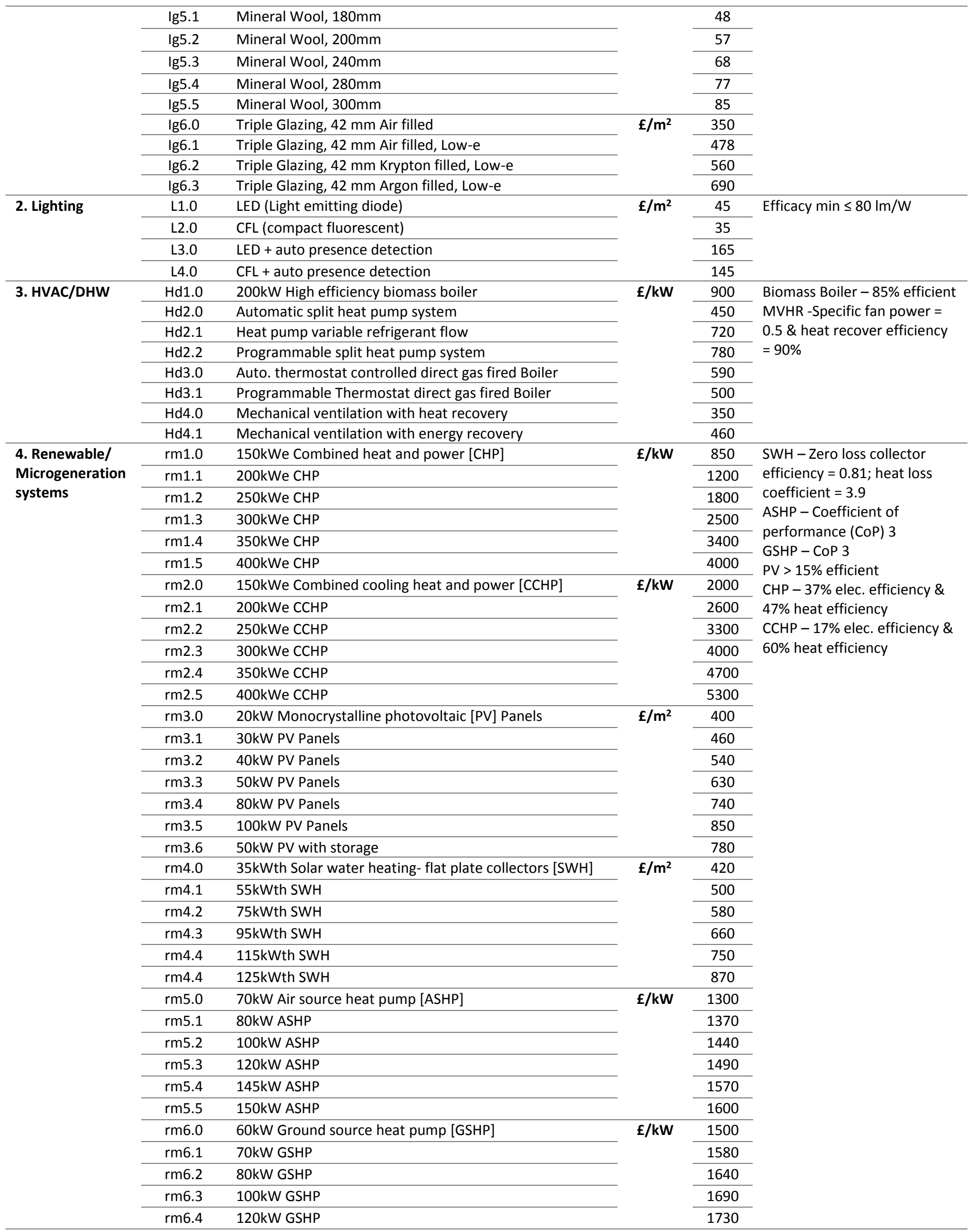




\subsection{Global Cost calculation}

The evaluation of the global costs is carried out over a 20-year study period. The 20-year study period is selected in accordance with the Commissions Guidelines for the global cost calculation of nonresidential buildings. Any currently applicable taxes (value added tax $-20 \%$ VAT), tax relief and/or incentive schemes are taken into consideration. As mentioned previously, building life cycle cost (BLCC) software is utilised to carry out this part of the methodology using the formulae and data presented in this section. The equation for the global cost is expressed as Equation 1 and is obtained from the Standard BS EN 15459-1:2017 [52]:

$$
C_{G}(\tau)=C O_{I N I T}+\sum_{j}\left[\sum_{i=1}^{\tau} C O_{a(i)}(j) x R_{d_{(i)}}-V A L_{f i n(\tau)}(j)\right]
$$

The global costs $C_{G}(\tau)$ referred to starting year $\tau_{0}$ are calculated by taking the sum of the initial investment costs $C O_{I N I T}$ for component $j$, the annual cost $C O_{a}$ for year $i$ which is discounted by the discount rate $R_{d}(i)$, and the residual value $V A L_{f i n}$ of component $j$ in year $T C$ at the end of the calculation period is referred to starting year $\tau_{0}$. The residual value refers to the remaining value of a measure or a retrofit scenario until the end of its lifespan. Residual values are calculated by linearly prorating the initial investment costs, for example, an EEM with a projected useful life of 40 years will have a residual value of approximately $50 \%$ of the initial investment costs of that measure.

The different elements making up the LCCs for each scenario are as follows: 'Energy costs,' 'Maintenance Costs,' 'Replacement Costs,' and 'Initial investment Costs.' Energy costs included fuel and electricity costs (space heating/cooling, DHW heating, lighting, ventilation, and auxiliary). Maintenance and replacement costs involved fabric and systems maintenance and replacements; annual servicing of boilers, windowpanes, C/CHP and Mechanical Ventilation (MV) filters; and possible typical servicing and repairs throughout the study period. Miscellaneous costs refer to any investment costs not related to the EEMs; they range from staff fees to planning application costs. The only investment costs included in the analysis are those directly related to the EEMs.

\subsection{Results and discussion}

\subsection{Model validation}

In order to evaluate the difference in energy performance before and after retrofit, the first step is to analyse the baseline model and validate that it's a true representation of the actual building. To validate the baseline model created on Tas, the simulated energy consumption value is compared against the building's actual energy consumption. As mentioned previously the site survey enables the development of a thorough model that reproduces all the characteristics and systems of the building as it currently stands.

The total energy consumption considers heating, cooling, auxiliary, lighting, domestic hot water (DHW), equipment, and displaced electricity (where applicable). The carbon emission calculations take into consideration building systems, air/ plan side HVAC control(s), building envelope elements 
(insulation, glazing etc.), lighting/daylighting interaction(s), energy consumption, occupancy schedule, fuel type, ventilation, DHW etc. Finally, the PEC is the amount of primary energy consumed in order to meet the building's energy demand (heating, cooling, DHW, lighting, and auxiliaries) and is also the net of any electrical energy displaced, where applicable.

Looking at figure 3 and equation 1 there is an $8 \%$ difference in energy consumption between the model and the actual energy consumption. This $8 \%$ is an underestimation of the actual energy consumption of the hotel. However, as demonstrated across the literature the performance gap cannot be completely closed at the moment [53-55]. Several complexities exist, especially the occupant's behaviour, which cannot be entirely assumed.

Furthermore, the weather data used in simulation studies will never replicate the microclimate of the building's location and it is typically not representative of a specific and real year but is based on averages, as discussed earlier. As a result, despite the high quality of input data used to develop the model it is reasonable that there remains a difference between simulated and actual energy consumption.

Looking at the energy profile for the actual energy consumption, there are unusual fluctuations in the energy consumption during certain months. The reason for this anomalous profile is due to the year that is selected. During 2018 the UK had uncharacteristically low temperatures and snow during February/March. Following this, a heatwave occurred during April and some of the warmest days on record were experienced [56,57].

However, when the annual energy consumption of the year 2018 is compared to the annual energy consumption of the previous 2 years, it is discovered that the difference in the total annual energy consumption between the 3 years is negligible $(<5 \%)$.

Consequently, it did not matter which year is utilised in this study as it did not have a significant effect on the results or the validation of the model. This suggests that the hotel's current energy consumption is affected by other factors and activities that are not weather dependant and that the hotel's energy management could be improved upon. A full climate control system is not included as part of the investigated EEMs because the benefits of such a system largely depends on occupant behaviour. Therefore, in a hotel setting it can only be utilised in certain public areas as guest comfort would always be a priority.

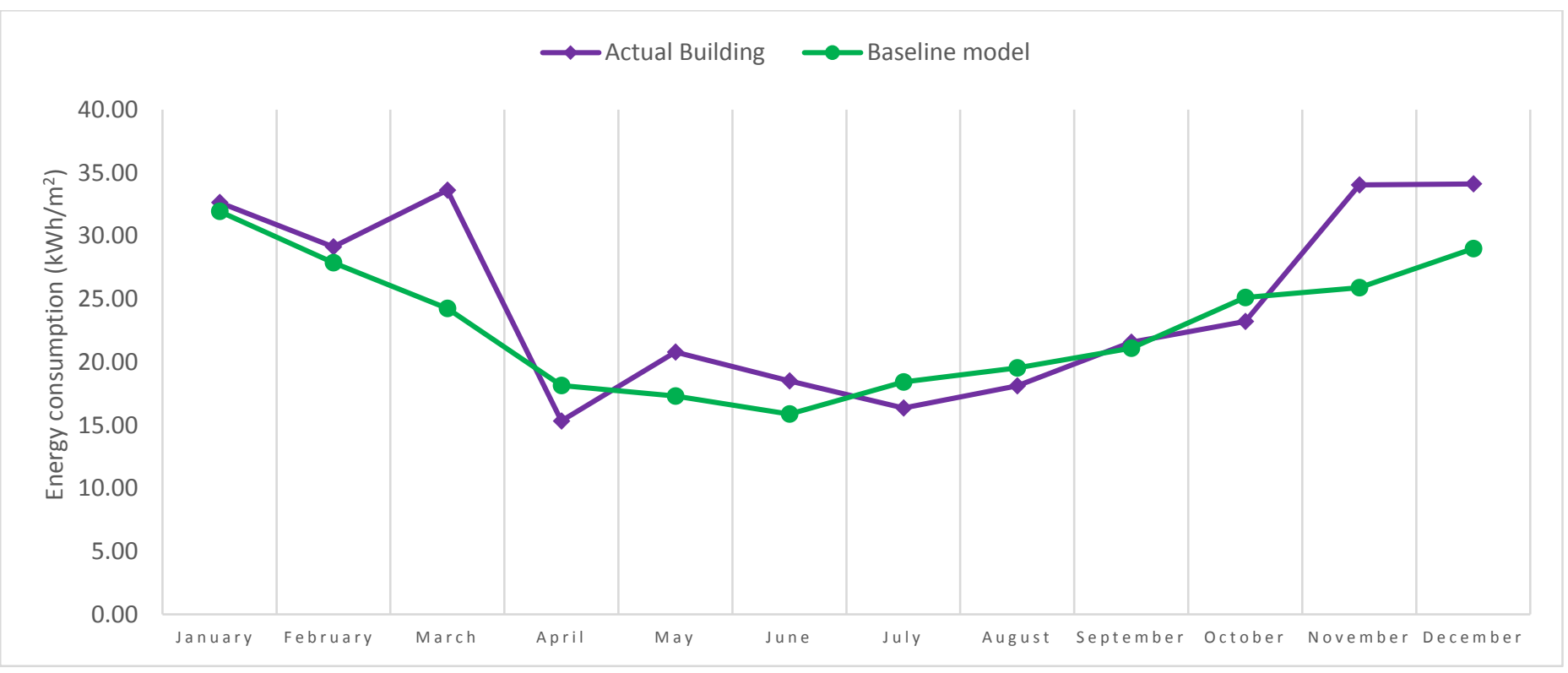


Figure 3: Comparison of the actual energy consumption (2018) against the modelled annual energy consumption

$$
\begin{aligned}
& \text { Percentage error }=\left(\frac{274.97-297.41}{274.97}\right) * x 100=-8 \% \\
& * \text { Unit: }\left(\mathrm{kWh} / \mathrm{m}^{2}\right)
\end{aligned}
$$

\subsection{Energy performance analysis}

Figures 4 and 5 show how the performance of the model varies in comparison to the nZEB target and relative to the baseline building. Between the four sets of packages there are clear differences in how they affect the energy performance of the hotel building. All the packages proved to be successful at meeting the carbon emissions target.

'Set 3 ' ensured that all the nZEB targets are met by incorporating that most suitable EEMs i.e. selective fabric, lighting, HVAC and renewable/ microgeneration systems. The packages within 'Set 3' can easily be considered the 'best performing' set of packages. This is demonstrated by figure 4 , which shows a significant difference in the PEC between the four different sets. The average percentage difference between the packages within 'Set 3 ' and 'Sets 1 and 2 ' is a considerable $44 \%$.

'Set 4' was comprised of packages that had small fabric and lighting improvements, assisted by significant HVAC improvements and renewable/ microgeneration systems. The retrofit packages within this set led to results that were the closest to 'Set 3'. On average packages within this set performed better than packages within 'Sets 1 and 2 ' by $17 \%$. Within this set, packages that incorporated SWH and PV did not work well to reduce the PEC. This is because these measures do not meet the significant heating and cooling energy needs of the hotel. This highlights the importance of incorporating not just any renewable/microgeneration system but selection of the most suitable system that meets the energy demands of the building being retrofitted.

Furthermore, although 'Set 4' performed very well in terms of reducing the PEC, the packages within this set did not meet the all the nZEB requirements. In general, the packages were adequate at lowering the PEC and carbon emissions. However, not all packages were able to meet the envelope requirements which meant that the energy demand of the building was not lowered to the nZEB standard.

Interestingly, 'Set 1 ,' which is comprised of packages with significant fabric and lighting improvements had very little/no variation in terms of energy performance. Regardless of which HVAC and renewable/microgeneration system is incorporated as part of the package, the PEC remained mostly unaffected. Packages within 'Set 2' produced very similar results to that of 'Set 1.' In general, packages within 'Set 1' and 'Set 2' underperformed in comparison to the packages in the other two sets. 'Sets 1 and 2 ' highlight the importance of incorporating an adequately sized renewable/ microgeneration system. The packages within these sets have similar investment costs to those of the other sets and despite this the nZEB target could not be met. This also has an impact on the operational costs and therefore LCCs. If the packages do not successfully reduce the PEC and therefore energy costs, then the investment cannot be justified.

In terms of $\mathrm{CO}_{2}$ reductions, all packages were able to meet the nZEB emissions target. Even with an undersized renewable/microgeneration systems packages within 'Set 1 and 2' were able to reach the required target. This suggests that fabric improvements and systems optimisation can be as important to reducing building emissions as renewable systems. The average percentage decrease in emissions between all sets was $53 \%$. 
구

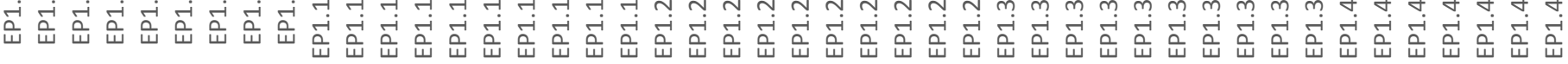

Scenario

PEC [Set 1] $(\mathrm{kWh} / \mathrm{m} 2 / \mathrm{yr})$

PEC [Set 4] $(\mathrm{kWh} / \mathrm{m} 2 / \mathrm{yr})$

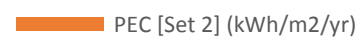

- - nZEB Target $(\mathrm{kWh} / \mathrm{m} 2 / \mathrm{yr}$
PEC [Set 3] (kWh/m2/yr)

- - PEC [before retrofit] $(\mathrm{kWh} / \mathrm{m} 2 / \mathrm{yr})$

Figure 4: Comparison of the primary energy consumption for the case study building before and after retrofit and the nZEB target

200

है

⿶凵

a

80

160

140

120

ก 100

.

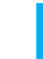

60

40

20

0

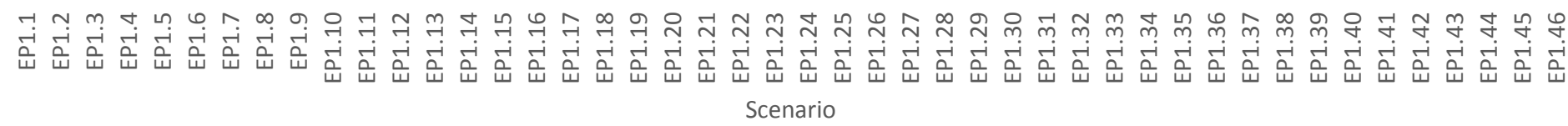

$\mathrm{CO} 2$ emissions [Set 1] $(\mathrm{Kg} / \mathrm{CO} 2 / \mathrm{m} 2 / \mathrm{yr})$

CO2 emissions [Set 4] $(\mathrm{Kg} / \mathrm{CO} 2 / \mathrm{m} 2 / \mathrm{yr})$
CO2 emissions [Set 2] (Kg/CO2/m2/yr)

- - nZEB Target (Kg/CO2/m2/yr)
$\mathrm{CO} 2$ emissions [Set 3] (Kg/CO2/m2/yr)

- - $\mathrm{CO} 2$ emissions [before retrofit] $(\mathrm{Kg} / \mathrm{CO} 2 / \mathrm{m} 2 / \mathrm{yr})$

Figure 5: Comparison of the carbon emissions for the case study building before and after retrofit and the nZEB target 


\subsection{Global Cost analysis}

The cost-optimal solution should ideally represent the best combination of the energy and cost performance. A balance between the two is necessary. A focus on just lowering the costs means the nZEB requirements are not met. Likewise, a focus on just meeting the nZEB standard with the current level and cost of technology renders the solution economically unfeasible. Figure 6 is showing the PEC of all the packages against the global costs; the cost optimal range and the nZEB target.

Certain packages did not meet the nZEB target at all. There is a clear distinction between the packages that made up the four different sets. Packages within 'Set 1 and 4' resulted in the highest global costs in comparison to the other two sets. Whilst majority of packages in set four met and exceeded the nZEB standard, the same is not true for packages in 'Set 1.' In fact, despite having the highest global costs, none of the packages in 'Set 1 ' met the nZEB target. As a result, the energy benefits gained by focussing on significant building fabric and lighting improvements is not justified by the associated global costs.

Packages within 'Set 2 and 3' also performed similarly in terms of their cost performance. However, 'Set three' had the lowest global costs on average in comparison to all the other sets. This highlights the importance of selecting a variety of EEMs that meet the building's energy demand, rather than focussing on one retrofit aspect and working around that.

The cost-optimal primary energy consumption value is $193.59 \mathrm{kWh} / \mathrm{m}^{2} / \mathrm{yr}$ as obtained from the costoptimal graph shown in figure 6. The nZEB target's primary energy consumption level is $150 \mathrm{kWh} / \mathrm{m}^{2} / \mathrm{yr}$. This $30 \%$ percent gap between the cost-optimal solution and the nZEB target is significant. However, considering the fact that the cost-optimal solution offered a reduction of $52 \%$ and $45 \%$ in primary energy consumption and global costs in comparison to the baseline scenario it can be said that it is still a viable option in terms of reducing the energy consumption but not fully meeting the nZEB standard. Therefore, the cost-optimal solution offered a considerable reduction in both energy and costs.

It may be that with the current level and price of EEMs available, finding a balance between the energy and cost benefits is one of the best options to carrying out energy retrofits and as such technologies become widespread in use, it is always possible to carry out further, albeit minor, retrofits in the future to fully meet the required standard.

To achieve a balance between the energy and cost requirements it is best to consider alternatives of certain measures. As opposed to neglecting to address specific requirements altogether. Even small changes in the type of measure selected (e.g. selecting $80 \mathrm{~mm}$ PIR not $110 \mathrm{~mm}$ ) can help reduce global cost. Thereby bridging the gap between the cost-optimal level and the nZEB level. In general, it can be said that it is difficult to keep the global costs to a minimum whilst ensuring that the building envelope meets the nZEB standard.

One of the main barriers to reaching the nZEB standard is typically the large investment costs. However, buildings have their own dynamics and are not static, therefore, at certain points they always require that old components are replaced. These points should, therefore, be seen as opportunities for improvement rather than replacement. In this manner the nZEB standard may also be achieved over stages rather than at once. This notion is corroborated by other studies discussed in the literature section earlier whereby the energy efficiency of buildings was improved by incorporating even one EEM and implementing a long-term plan for further improvements. It should be highlighted that the reduction in the PEC and global costs of $52 \%$ and $45 \%$ was achieved by incorporating a variety 
of EEMs. The solution provided a balance between the reduction in energy consumption and costs over the study period.

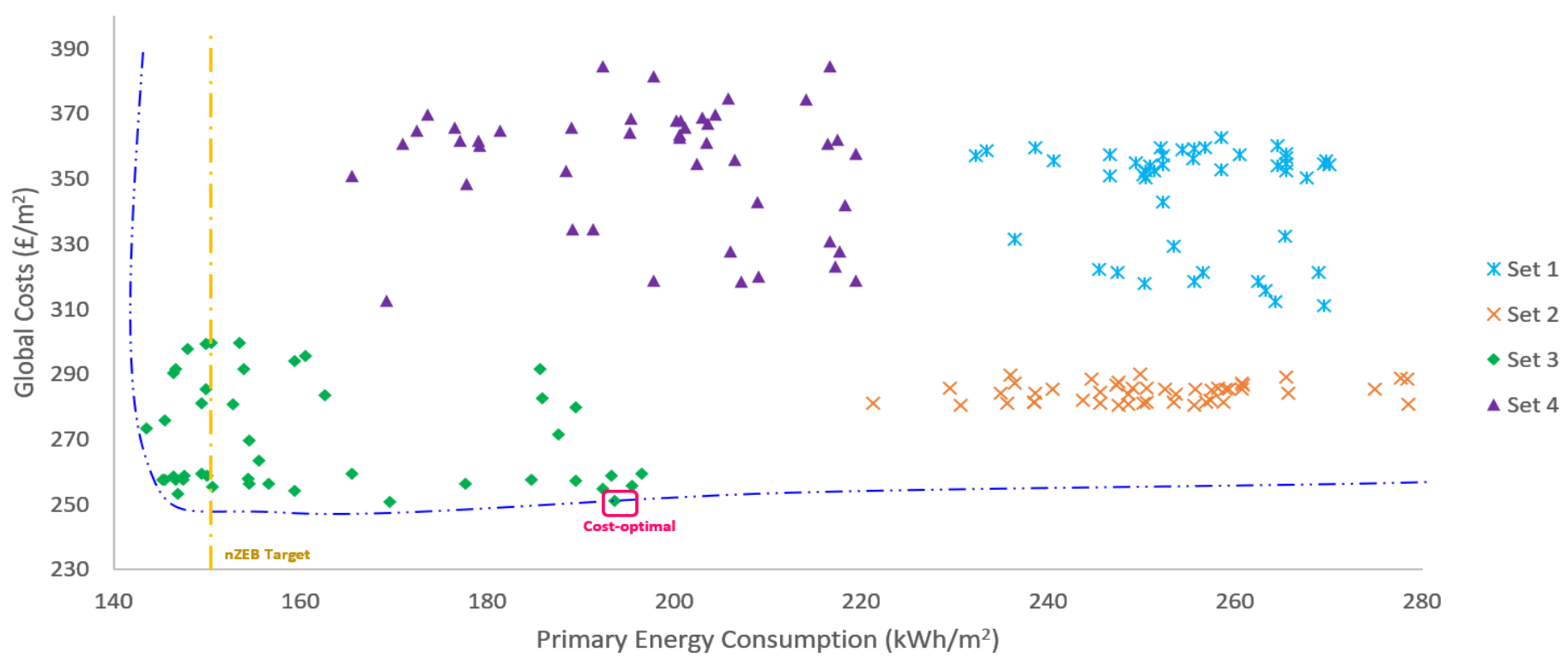

Figure 6: Cost-optimal curve graph showing the global costs against the primary energy consumption of the different packages

\subsection{Summary}

This paper presented an energy performance and cost analysis post-nZEB retrofit for a typical UK hotel. Using dynamic thermal analysis simulation software Tas Edsl, the energy performance of the hotel as it currently stands and as a nZEB was examined and compared. To ensure the validity of the results a comprehensive and accurate baseline model was created following a site investigation. As a result, a performance gap between the actual and modelled energy performance of less than $9 \%$ was obtained. Initially, realistically applicable EEMs were individually selected. Following this, they were combined using TasGenOpt to create the retrofit packages. Finally, the global costs of the various retrofit packages were evaluated and based on this a cost-optimal range was defined. Based on the findings the following recommendations are provided:

The four different sets of retrofit packages assumed various priorities when grouping the EEMs. Adopting this methodology whereby different retrofit packages focussed on different potential retrofit aspects highlighted that a whole-building retrofit is the best route to achieving the nZEB standard. Prioritising one aspect of retrofitting and neglecting another simply leads to an 'incomplete' retrofit that either fails in lowering the energy demand of the building or in improving the overall energy efficiency of systems and components.

The comparison of the retrofit variants within a certain set showed the importance of selecting not just a range of EEMs that work together to meet the standard but rather a range of 'suitable' EEMs. Suitability always depends on the baseline building and its current energy demand and usage. For example, for this case study the most compatible renewable/microgeneration measures were ones that offered a balance between the heating and cooling needs during the heating and non-heating season. As a result, measures that only focussed on meeting the heating needs underperformed at reducing the $\mathrm{PEC}$. 
To bridge the gap between the nZEB solution and the cost-optimal one certain trade-offs may be necessary. For example, Comparing the results between and within the different sets of retrofit packages demonstrated that it is possible to reduce the global costs by finding alternative EEMs with lower investment costs.

Overall, the presented case study has demonstrated that the nZEB standard is achievable with cost benefits. The methodology utilised in this paper can be replicated with any other commercial building. The energy validation process ensures that the results obtained are reliable. However, to increase the reliability of the cost calculation a homogeneous cost database for such UK retrofit projects is necessary. When this occurs, the specific cost results of such studies can be applicable to many buildings of similar stock. A comprehensive and applicable database requires several phases to be successfully utilised and will need to be defined based on location too as this can greatly affect the cost of measures.

Author contributions: Ali Bahadori-Jahromi, Anastasia Mylona, Paulina Godfrey and Darren Cook conceived and designed the project. Radwa Salem performed the experiments, analysed the data, and wrote the paper. Ali Bahadori-Jahromi, Anastasia Mylona, Paulina Godfrey and Darren Cook reviewed the paper.

Funding: The author(s) received no financial support for the research, authorship, and/or publication of this article.

\section{References}

1. Digest of UK Energy Statistics (DUKES), UK Energy in Brief 2018 https://www.gov.uk/government/uploads/system/uploads/attachment_data/file/631146/UK_Energy_in_Brief_2017.pdf. (Accessed 24th July 2019).

2. European Commission (EC), Eurostat: Key European statistics. http://epp.eurostat.ec.europa.eu/. (Accessed 25th July 2019).

3. Attia S. Zero Energy Retrofit Case Study of a chalet in Ain-Sukhna, Egypt. American Solar Energy Society Conference, 217-222, May 2010, Phoenix, Arizona, USA.

4. Garde F, Ayoub J, Aelenei D, Aelenei L, Scognamiglio A. Solution Sets for Net Zero Energy Buildings. Berlin, Germany: Wilhelm Ernst \& Sohn. 2017; 46-86.

5. Salem R, Bahadori-Jahromi A, Mylona A, Godfrey P, Cook D. Life Cycle Cost analysis of energy efficient retrofit scenarios for a UK residential dwelling. Eng Sustain; 2020; 173(2): 57-72. https://doi.org/10.1680/jensu.18.00055

6. Asdrubali F, Ballarini I, Corrado V, Evangelisti L, Grazieschi G, Guattari C. Energy and environmental payback times for an NZEB retrofit. Build Environ 2019; 147:461-472. https://doi.org/10.1016/j.buildenv.2018.10.047

7. Epbd recast, Directive 2010/31/EU of the European Parliament and of the Council of 19 May 2010 on the Energy Performance of Buildings (Recast), Off. J. Eur.Union, 2010.

8. Epbd revised, Directive (EU) 2018/844 of the European Parliament and of the Council of 30 May 2018 Amending Directive 2010/31/EU on the Energy Performance of Buildings and directive 2012/27/EU on Energy Efficiency, Off. J.

9. Boermans T, Bettgenhäuser K, Hermelink A, and Schimschar S. (2011) Cost Optimal Building Performance Requirements. Calculation Methodology for Reporting on National Energy Performance Requirements on the basis of cost optimality within the Framework of the EPBD. European Council for an Energy Efficient Economy, Sweden. https://www.eurima.org/uploads/ModuleXtender/Publications/57/cost_optimality-eceee_report.pdf

10. Heljo Juhani; Vihola Jaakko. 2012. Energiansäästömahdollisuudet rakennuskannan korjaustoiminnassa. Tampereen teknillinen yliopisto. Rakennustekniikan laitos. Rakennustuotanto- ja talous. Raportti 8. http://www.tut.fi/ee/Materiaali/Epat/EPAT_loppuraportti.pdf.

11. Visscher H, Meijer F, Majcen D, Itard L. Improved governance for energy efficiency in housing. Build. Res. Inf. 2016; 44 (5): $552-$ 561. https://doi.org/10.1080/09613218.2016.1180808

12. Delzendeh E, Wu S, Lee A, Zhou Y. The impact of occupnats' behaviours on building energy analysis: A research review. Renew. Sustain. Energy Rev, 2017; 80: 1061-1071. https://doi.org/10.1016/j.rser.2017.05.264

13. Environmental Design Solutions Limited (EDSL). http://www.edsl.net/. (accessed 19th June 2019). 
14. Hotel Energy Solutions (HES). Analysis on energy use by European hotels.

http://hes.unwto.org/sites/all/files/docpdf/analysisonenergyusebyeuropeanhotelsonlinesurveyanddeskresearch2382011-1.pdf. (accessed 26th July 2019].

15. neZEH - Nearly zero energy Hotels. http://www.nezeh.eu/home/index.html. (accessed 15th July 2019].

16. Bohdanowicz P. Environmental awareness and initiatives in the Swedish and Polish hotel industries - Survey results. Int. J. of Hos. Manage., 2005; 21: 57-66. https://doi.org/10.1016/j.ijhm.2005.06.006

17. Le Y, Hollenhorst S, Harris C, McLaughlin W, and Shook S. Environmental management: A study of Vietnamese hotels. Ann. Tour. Res., 2006; 33(2): 545-567. https://doi.org/10.1016/j.annals.2006.01.002

18. Lu S, Wei S, Zhang K, Kong X, and Wu W. Investigation and analysis on the energy consumption of starred hotel buildings in Hainan Province, the tropical region of China. Energ. Convers. Manage., 2012; 75: 570-580. https://doi.org/10.1016/j.enconman.2013.07.008

19. Radwan H, Jones $E$, and Minoli D. Solid waste management in small hotels: A comparison of green and non-green small hotels in Wales. J. of Sustain. Tour., 2011; 20(4): 533-550. https://doi.org/10.1080/09669582.2011.621539

20. Pirani S A and Arafat H A. Solid waste management in the hospitality industry: A review. J. Environ. Manage. 2014; 146: 320-336 doi: 10.1016/j.jenvman.2014.07.03

21. Paoletti G, Pascuas P R, Pernetti R, Lollini R. Nearly Zero Energy Buildings: An Overview of the Main Construction Features across Europe. Build., 2017; 7(4): 43. http://dx.doi.org/10.3390/buildings7020043.

22. Tsoutsos T, Tournaki S, Frangou M, Tsitoura M. Creating paradigms for nearly zero energy hotels in south Europe. AIMS-Energy, 2018; 6(1): 1-18. doi: 10.3934/energy.2018.1.1.

23. Buso T, Becchio C, Corgnati S P. NZEB, cost- and comfort-optimal retrofit solutions for an Italian Reference Hotel. Energy Procedia, 2017; 140 (11): 217-230.

24. Marszal A, Heiselberg P, Bourrelle J, Musall E, Voss K, Sartori I, Napolitano A. Zero energy building - a review of definitions and calculation methodologies. Energ. and Build., 2011; 43: 971-979. https://doi.org/10.1016/j.enbuild.2010.12.022

25. D'Agostino D, Zangheri P, Cuniberti B, Paci D, Bertoldi P. Synthesis Report on the National Plans for Nearly Zero Energy Buildings (NZEBs). http://publications.jrc.ec.europa.eu/repository/ bitstream/JRC97408/reqno_jrc97408_online\%20nzeb\%20report.pdf (accessed 23rd July 2019).

26. Salem R, Bahadori-Jahromi A, Mylona A, Godfrey P, Cook D. Investigating the potential impact of energy efficient measures for retrofitting existing UK hotels to reach the Nearly-Zero Energy Building (nZEB) standard. Energ. Eff., 2019; 12(6): 1577-1594. https://doi.org/10.1007/s12053-019-09801-2

27. Tournaki S, Frangou M, Tsoutsos T, Morell R, Guerrero H, Derjanecz A. Nearly Zero Energy Hotels - from European Policy to Real Life Examples: the neZEH Pilot Hotels, 2014.

28. Cunha F. O, Oliveira A. C. Benchmarking for realistic nZEB hotel buildings. J. Build. Energ., 2020; 30: 101298. https://doi.org/10.1016/j.jobe.2020.101298

29. Corradoa V, Muranoa G, Paduosa S, Rivab G. On the refurbishment of the public building stock toward the nearly, zero-energy target: two Italian case studies. Energ. Procedia, 2016; 101: 105-112. https://doi.org/10.1016/j.egypro.2016.11.014

30. Martinopoulos G. Life Cycle Assessment of solar energy conversion systems in energetic retrofitted buildings. J. Build. Eng, 2018; 20:256-263. https://doi.org/10.1016/j.jobe.2018.07.027

31. Simons A, Firth S.K. Life-cycle assessment of a 100\% solar fraction thermal supply to a European apartment building using waterbased sensible heat storage. Energ. Build, 2011; 43:1231-1240. https://doi.org/10.1016/j.enbuild.2010.12.029.

32. Zangehri P, Armani R, Pietrobon M, Pagliano L. Identification of cost-optimal and NZEB refurbishment levels for representative climates and building typologies across Europe. Energ. Eff., 2017; 11(2): 337-369. https://doi.org/10.1007/s12053-017-9566-8

33. Zebra 2020. Nearly Zero Energy Building Strategy 2020-Strategies for a Nearly Zero-Energy Building Market Transition in the European Union. http://zebra2020.eu/website/ wp-content/uploads/2014/08/ZEBRA2020_Strategies-for-nZEB_07_LQ_singlepages-1.pdf (accessed 23rd July 2019).

34. Ali Y, Mustafa M, Al-Mashaqbah S, Mashal K, and Mohsen M. Potential of energy savings in the hotel sector in Jordan. Energ. Convers. Manage., 2008; 49 (9): 3391-33972. https://doi.org/10.1016/j.enconman.2007.09.036

35. Nocera F, Giuffrida S, Trovato MR, Gagliano A. Energy and new economic approach for Nearly Zero Energy Hotels. Entropy, 2019; 21 (7): 639-654. https://doi.org/10.3390/e21070639 
36. Butler J. The Compelling “Hard Case" for “Green” Hotel Development. Cornell Hosp. Q., 2008; 49(3): $234-244$. https://doi.org/10.1177/1938965508322174

37. Dolnicar SI, Crouch G.I, and Long P. Environment friendly tourists: What do we really know about them? J. Sustain. Tour, 2008; 16(2): 197-210. DOI:10.2167/jost738.0

38. Kostakis I, and Sardianou E. Which factors affect the willingness of tourists to pay for renewable energy? Renew. Energ., 2012; 38 (1): 169-172. https://doi.org/10.1016/j.renene.2011.07.022

39. Chen $\mathrm{M}$ and Tung P.J. Developing an extended Theory of Planned Behavior model to predict consumers' intention to visit green hotels. Int. J. Hosp. Manage. 2014; 36(6): 221-230. https://doi.org/10.1016/j.ijhm.2013.09.006

40. Cingoski V and Petrevska B. Making hotels more energy efficient: the managerial perception. Econom. Res., 2018; 31(1): 87-101. https://doi.org/10.1080/1331677X.2017.1421994

41. BS EN 16798-1:2019, Energy performance of buildings. Ventilation for buildings. Indoor environmental input parameters for design and assessment of energy performance of buildings addressing indoor air quality, thermal environment, lighting and acoustics. BSI, ISBN: 9780580858680

42. Amoako-Attah J, and B-Jahromi A. Impact of standard construction specification on thermal comfort in UK dwellings. Adv. Environ. Res., 2014; 3(3): 253-281. DOI: 10.12989/aer.2014.3.3.253

43. Wetter $\mathrm{M}$, and Wright J. A comparison of deterministic and probabilistic optimization algorithms for non-smooth simulationbased optimization. Build. Environ., 2004; 39: 989-999. https://doi.org/10.1016/j.buildenv.2004.01.022

44. Hasan A, Mika V, and Siren K. Minimization of life cycle cost of a detached house using combined simulation and optimization. Energ. Build., 2008; 48: 2022-2034. https://doi.org/10.1016/j.buildenv.2007.12.003

45. Alanne K, Salo A, Saari A and Gustafsson SI (2007) Multi-criteria evaluation of residential energy supply systems. Energ. Build., 2007; 39(12): 1218-1226. https://doi.org/10.1016/j.enbuild.2007.01.009

46. Karaguzel OT, Zhang R and Lam KP. Coupling of whole-building energy simulation and multi-dimensional numerical optimization for minimizing the life cycle costs of office buildings. Build. Simul., 2014; 14(7): 111-121. https://doi.org/10.1007/s12273-0130128-5

47. Chartered Institute of Building Services Engineers, CIBSE Weather Data Sets. Cibse, London, UK. http://www.cibse.org.uk/knowledge/cibse-weather-data-sets (accessed 19th July 2019).

48. Eames M.E, Ramallo-Gonzalez A.P, and Wood M.J. An update of the UK's test reference year: The implications of a revised climate on building design. Build. Serv. Eng. Res. Tech., 2016; 37: 316-3333. https://doi.org/10.1177/0143624415605626

49. Mylona, A. Revision of Design Summer Years and Test Reference Years. Cibse, London, UK, 2017. http://www.cibse.org/getmedia/cc7072d9-8e58-42cb-83ce-2316546f0aa0/Introduction-to-CIBSE-Weather-Data-Files.pdf.aspx. (accessed 10th July 2019).

50. Dixon T. An analysis of emergent retrofit practices in the UK commercial property sector. Project Report. EPSRC Retrofit 2050, 2014, Cardiff. ISSN 2052-1618

51. BS EN 15459-1:2017. (2017). Energy performance of buildings. Economic evaluation procedure for energy systems in buildings Calculation procedures, Module M1-14. BSI, ISBN: 9780580874529

52. Knight I, Stravoravdis S, Lasvaux S. Predicting operational energy consumption profiles - findings from detailed surveys and modelling in a UK educational building compared to measured consumption. Int. J. Vent., 2008; 97: 355-364. https://doi.org/10.1080/14733315.2008.11683798

53. Collins L. Predicting annual energy consumption with thermal simulation. Build. Simul., 2012; 5(1): 117-125. https://doi.org/10.1007/s12273-012-0074-7

54. Gucyeter B, and Gunaydin HM. Optimisation of an envelope retrofit strategy for an existing office building. Energ. Build., 2012; 55: 647-659. https://doi.org/10.1016/j.enbuild.2012.09.031

55. BBC News, 'Mini Beast from the East' brings snow and ice to parts of UK. https://www.bbc.co.uk/news/uk-43439807. (accessed 25th July 2019).

56. Telegraph, April mini heatwave 2018 - how long we can expect warm British weather to last. https://www.telegraph.co.uk/news/2018/04/19/april-mini-heatwave-2018-long-can-expect-warm-british-weather/. (accessed 16th July 2019).

57. Department for Business, Energy and Industrial Strategy (BEIS), Retrofit for the Future: analysis of cost data. A https://www.gov.uk/government/publications/retrofit-for-the-future-analysis-of-cost-data. (accessed 20th July 2019). 
58. GOV.UK. https://www.gov.uk/guidance/2050-pathways-analysis. (accessed 26th June 2019). 